\title{
Using Carbon Isotope Equilibrium to Screen Pedogenic Carbonate Oxygen Isotopes: Implications for Paleoaltimetry and Paleotectonic Studies
}

\author{
Nathan D. Sheldon (D) \\ Department of Earth and Environmental Sciences, University of Michigan, Ann Arbor, MI 48109, USA \\ Correspondence should be addressed to Nathan D. Sheldon; nsheldon@umich.edu
}

Received 31 March 2018; Accepted 23 September 2018; Published 10 December 2018

Academic Editor: John A. Mavrogenes

Copyright (C) 2018 Nathan D. Sheldon. This is an open access article distributed under the Creative Commons Attribution License, which permits unrestricted use, distribution, and reproduction in any medium, provided the original work is properly cited.

\begin{abstract}
Stable isotope compositions of pedogenic carbonates $\left(\delta^{13} \mathrm{C}_{\mathrm{carb}}, \delta^{18} \mathrm{O}_{\text {carb }}\right)$ are widely used in paleoenvironmental and paleoaltimetry studies. At the same time, both in vertical stratigraphic sections and in horizontal transects of single paleosols, significant variability in $\delta^{18} \mathrm{O}_{\text {carb }}$ values is observed well in excess of what could reasonably be attributed to elevation changes. Herein, a new screening tool is proposed to establish which pedogenic carbonate $\delta^{18} \mathrm{O}_{\text {carb }}$ compositions reflect formation in isotopic equilibrium with environmental conditions through the use of the co-occurring $\delta^{13} \mathrm{C}_{\text {org }}$ composition of carbonate-occluded or in profile organic matter, where $\Delta^{13} \mathrm{C}=\delta^{13} \mathrm{C}_{\text {carb }}-\delta^{13} \mathrm{C}_{\text {org }}$. Based upon 51 modern soils from monsoonal, continental, and Mediterranean moisture regimes, $\Delta^{13} \mathrm{C}=+15.6 \pm 1.1 \%$ o $(1 \sigma)$, which closely matches theoretical predictions for carbonates formed at carbon isotope equilibrium through Fickian diffusion. Examples from both disequilibrium and equilibrium cases in the geologic record are examined, and it is shown that previous $\delta^{18} \mathrm{O}_{\text {carb }}$ records used to infer Cenozoic uplift in southwestern Montana do not provide any constraint on paleoelevation because $>90 \%$ of the pedogenic carbonate isotopic compositions are out of equilibrium. Guidelines for future paleoaltimetry studies include collection of both vertical stratigraphic sections and lateral transects, of at least three nodules per horizon, petrographic screening of nodules for diagenesis, collection of at least one independent proxy for paleoclimate or paleovegetation, and screening $\delta^{18} \mathrm{O}_{\text {carb }}$ values using $\Delta{ }^{13} \mathrm{C}$ measured for each paleosol.
\end{abstract}

\section{Introduction}

In many environments, soils form carbonate $\left(\mathrm{CaCO}_{3}\right)$ nodules in response to seasonal drying of $\mathrm{HCO}_{3}{ }^{-}$-rich interstitial water, which leads to carbonate supersaturation (e.g., $[1,2])$. While formation of pedogenic carbonates is most common in arid to subhumid environments $\left(<750 \mathrm{~mm} \mathrm{yr}^{-1}\right.$; [3]), under strongly seasonal climatic regimes, pedogenic carbonate may form under much wetter conditions in a mean annual sense. As a result, pedogenic carbonate is nearly ubiquitous in the Phanerozoic geologic record at least at the regional scale (e.g., Figure 19 of [4]). Because the $\mathrm{C}$ and $\mathrm{O}$ isotopic composition of pedogenic carbonate reflects the isotopic composition of fluid that it precipitated from the time of their formation (e.g., $[5,6])$, pedogenic carbonates have been widely used for reconstructing past environmental conditions.
Carbon isotopic compositions $\left(\delta^{13} \mathrm{C}_{\text {carb }}\right)$ have been used to reconstruct the composition of paleovegetation (e.g., [7]; Fox and Koch, 2003) and have been used in concert with $\mathrm{C}$ isotopic compositions of co-occurring organic matter $\left(\delta^{13} \mathrm{C}_{\text {org }}\right)$ to reconstruct paleo- $\mathrm{CO}_{2}$ levels $([8-10]$ and many others) and paleo-productivity (e.g., [11, 12]). Values for $\delta^{13} \mathrm{C}_{\text {carb }}$ can reflect up to three sources of $\mathrm{CO}_{2}$ (e.g., [4]): (1) open-system oxidation of soil organic matter, (2) atmospheric $\mathrm{CO}_{2}$, and (3) $\mathrm{CO}_{2}$ derived from preexisting carbonate. In general, pedogenic carbonate derived from only the first component of $\mathrm{CO}_{2}$ is restricted to swampy or wetland environments (e.g., $[6,13])$ and pedogenic carbonate formed from all three components only occurs in places where the soil parent material was derived from lacustrine or marine limestones. Thus, most pedogenic carbonates represent a two-component mixture of $\mathrm{CO}_{2}$ derived from oxidation of soil organic matter and atmospheric $\mathrm{CO}_{2}$. 
Oxygen isotopic compositions $\left(\delta^{18} \mathrm{O}_{\text {carb }}\right)$ of pedogenic carbonates reflect both the temperature of precipitation and $\delta^{18} \mathrm{O}$ composition of the fluid that the carbonates crystallized from (e.g., [14]), and as a result, have been used to reconstruct both of those variables by assuming the other, through an independent constraint on one variable or other, and more recently, through the use of "clumped isotope" measurements, which produce temperatures that are independent of the starting fluid isotopic composition. The underlying assumption in this is that the carbonates formed in equilibrium with their environmental conditions (e.g., reviewed by Quade et al. [15]). While a few studies have focused on $\delta^{18} \mathrm{O}_{\text {carb }}$ for purely climatological purposes (e.g., $[16]), \delta^{18} \mathrm{O}_{\text {carb }}$ has most often been used to consider tectonic questions. When an air mass rises over a topographic impediment, the meteoric $\delta^{18} \mathrm{O}$ value of the remaining water vapor becomes progressively more negative due to Rayleigh distillation (e.g., [17]). As a result, $\delta^{18} \mathrm{O}_{\text {carb }}$ values of pedogenic carbonates that formed at higher elevations are isotopically more negative relative to those formed at lower elevations. Because the relationship between elevation and meteoric water $\delta^{18} \mathrm{O}$ can be estimated either globally [18] or on a region-to-region basis (e.g., [19-21]), changes in $\delta^{18} \mathrm{O}_{\text {carb }}$ through a stratigraphic succession can be used to backcalculate elevation change through time.

1.1. Challenges of Using $\delta^{18} O_{\text {carb }}$ for Paleoaltimetry Studies. A variety of potential challenges of using $\delta^{18} \mathrm{O}_{\text {carb }}$ data as a tool for deciphering paleoaltimetry have been raised including how pure the carbonate mineral phase is (e.g., $100 \%$ calcite versus other mixtures), variations in the amount of meteoric precipitation at the time of carbonate formation, variations in the $\delta^{18} \mathrm{O}$ composition of the meteoric water in space, time, and seasonally, changes in climatic temperatures through time, among others (for an in-depth review, see [15]). As a result of these complications, in many terrestrial carbonate data series, there is a substantial spread in the measured $\delta^{18} \mathrm{O}_{\text {carb }}$ values. For example, Figure 1 shows a long-term $\delta^{18} \mathrm{O}_{\text {carb }}$ record compiled from carbonates in Montana and Idaho that has been used to interpret a significant uplift event between 50 and $30 \mathrm{Ma}$ ago (data from [22]), in which, for some five million year time bins, the spread in $\delta^{18} \mathrm{O}_{\text {carb }}$ exceeds $13 \%$. Two different potential interpretive frameworks are shown using those data within the context of the global $\delta^{18} \mathrm{O}$ lapse rate $\left(\sim 2.8 \% \mathrm{~km}^{-1}\right.$; [18]); one that assumes that the maximum range between high and low $\delta^{18} \mathrm{O}_{\text {carb }}$ values represents maximum possible uplift of $\sim 4.5 \mathrm{~km}$, and a second one that uses the mean $\delta^{18} \mathrm{O}_{\text {carb }}$ values before and after a depositional hiatus from 32-24 Ma ago to infer just $0.6 \mathrm{~km}$ of uplift. To be clear, neither of these scenarios was favored by the authors, but they illustrate the scale of the potential uncertainty in using all of the measured $\delta^{18} \mathrm{O}_{\text {carb }}$ data without regard to any consideration of "good" versus "bad" data points.

A second issue that was raised recently by Hyland and Sheldon [23] concerns the stratigraphic fidelity of single vertical stratigraphic sections. Those authors measured $\delta^{18} \mathrm{O}_{\text {carb }}$ values from a single paleosol over a multi-km lateral transect and found a range of $\sim 8 \%$ (Figure 2). The star in Figure 2

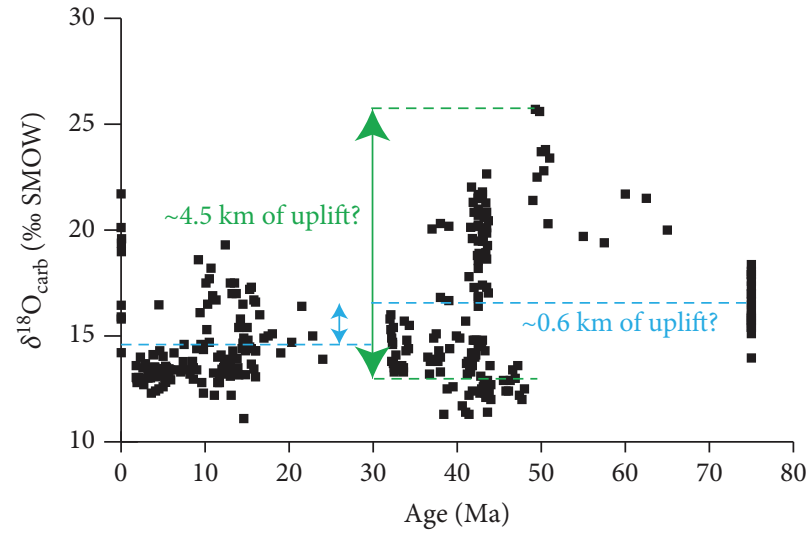

Figure 1: Plot of $\delta^{18} \mathrm{O}_{\text {carb }}$ for the past $75 \mathrm{Ma}$ from Montana and Idaho. Data are from Chamberlain et al. [22]; age assignments reflect the assignments in the original data set; however, it should be noted that some of the individual sites have been redated subsequently (e.g., [47]). Shown in green is the maximum potential uplift between $\sim 50$ and $\sim 30 \mathrm{Ma}$ ago, and in blue, a conservative estimate based upon long term means before and after a regional unconformity between 32 and $24 \mathrm{Ma}$ ago. Uplift estimates are based upon the global $\delta^{18} \mathrm{O}$ lapse rate of Poage and Chamberlain [18].

gives the value of the previous paleosol in the vertical succession, and the circles give the potential paleoelevation change that one could interpret in spite of $<5 \mathrm{~m}$ difference in stratigraphic height between the two pedogenic carbonatebearing paleosols. The range in interpretations is from little or no change to nearly two $\mathrm{km}$ of instantaneous uplift. Which, if any, of those results seem credible?

While the recent development of "clumped isotope" geochemistry of pedogenic carbonates promises to improve paleoaltimetry studies (e.g., reviewed by [15]) and to alleviate some of the issues raised above, it is a comparatively higher cost (both analytically and in terms of time) technique and requires significantly larger samples sizes. In addition, because massive archives of conventional $\delta^{18} \mathrm{O}_{\text {carb }}$ already exist, having tools to screen them directly would substantially improve future paleoaltimetry studies as well as making it possible to refine existing interpretations. Here, I will propose a new interpretive framework for understanding $\delta^{18} \mathrm{O}_{\text {carb }}$ values from pedogenic carbonates to improve terrestrial paleoclimate reconstructions and paleoaltimetric reconstructions.

\section{Methods}

To refine the use of $\delta^{18} \mathrm{O}_{\text {carb }}$ values from paleosols in paleoaltimetry studies, I will look at carbon isotope equilibrium as a screening tool. Modern soil samples were collected from nine separate pits from two different soil series in Arizona, USA. The Guvo soil series $(n=5)$ represents a calcic Aridisol formed at a mean annual temperature (MAT) of $21.7^{\circ} \mathrm{C}$ and a mean annual precipitation of $232 \mathrm{~mm} \mathrm{yr}^{-1}$. The Delthorny soil series $(n=4)$ represents a calcic Aridisol formed at an MAT of $21.6^{\circ} \mathrm{C}$ and an MAP of $304 \mathrm{~mm} \mathrm{yr}^{-1}$. Most of the precipitation for both soil series is delivered in the spring, 


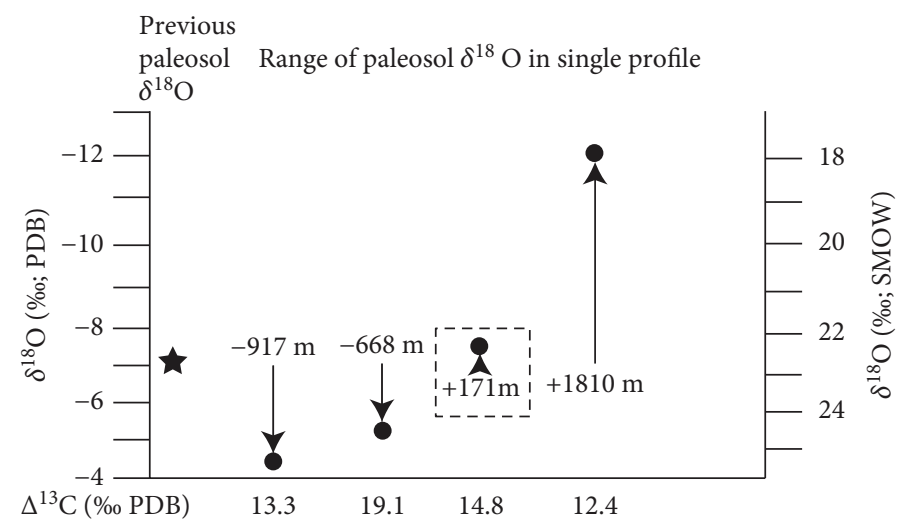

FIgURe 2: Plot of $\delta^{18} \mathrm{O}_{\text {carb }}$ data from a single paleosol horizon from the early Eocene Wasatch Formation (Wyoming, USA). Theoretical uplift or denudation estimates for individual paleosols along the transect based upon the global $\delta^{18} \mathrm{O}$ lapse rate of Poage and Chamberlain [18]. The samples outlined by the dashed box is the only one that is in $\mathrm{C}$ isotope equilibrium (see text for details).

as both sites are located within the monsoon belt for the southwestern US. Both soil series preserve pedogenic carbonate as nodules and as coatings on rock fragments. Bulk soil was collected at 2-3 sample depths within the upper $30 \mathrm{~cm}$ of each profile as well as intact roots. For all but one of the soil pits where there was little carbonate present, three carbonate nodules were collected from each soil pit. Samples for organic isotope analysis were decarbonated in weak $\mathrm{HCl}(2 \%)$, dried, homogenized, and measured into tin capsules for analysis. Organic carbon isotopes $\left(\delta^{13} \mathrm{C}_{\text {org }}\right)$ were measured at the University of Michigan's Stable Isotope Lab on a Delta V+ IRMS coupled to a Costech ECS 4010 elemental analyzer; results were calibrated against IAEA sucrose and caffeine standards and are presented relative to the PDB scale. External reproducibility was better than $0.1 \%$ for both standards and replicates. Carbonate stable isotope compositions $\left(\delta^{13} \mathrm{C}_{\text {carb }}\right.$ and $\left.\delta^{18} \mathrm{O}_{\text {carb }}\right)$ were obtained on micro-drilled samples of micritic carbonate $(n=3$ per nodule) that were analyzed on a Thermo 253 IRMS coupled to a Kiel IV autosampler; results were calibrated against NBS-19 and internal standards, and results are presented relative to the PDB scale for $\mathrm{C}$ and the SMOW scale for oxygen. External reproducibility was better than $0.04 \%$ o for both standards and replicates.

Precipitation $\delta^{18} \mathrm{O}$ estimates for the Guvo and Delthorny soil pit sites were obtained using the Online Isotopes in Precipitation Calculator (OIPC; [24]), using latitude, longitude, and elevation for each site. The OIPC uses data from IAEA precipitation monitoring sites and interpolates for sites located between observational record sites. Previously published data for modern soils come from Cerling and Quade [25] and Tabor et al. [6], and the geologic data for discussion come from $[22,26,27]$ and $[23,28]$. All of the new data are compiled in the Supplemental Materials (available here).

2.1. Interpretational Framework. Cerling [2, 9] presented a foundational understanding of the stable isotope values of pedogenic carbonates, and an updated discussion of subsequent work can be found in a recent review paper by Sheldon and Tabor [4]. Briefly though, the $\delta^{13} \mathrm{C}_{\text {carb }}$ value of pedogenic carbonates should reflect a mixture of up to three components of $\mathrm{CO}_{2}$ as described above. By general practice, three-component (i.e., with inherited carbonate) pedogenic carbonate is avoided, because it is extremely difficult to deconvolve the contribution of $\mathrm{CO}_{2}$ from inherited carbonate from the authigenic sources. In other words, paleosols with carbonate in their parent material are avoided. Isotopic compositions of two-component pedogenic calcites (i.e., those derived from soil-respired $\mathrm{CO}_{2}$ and atmospheric $\mathrm{CO}_{2}$ ) will reflect the depth position within the soil [2], and studies of in situ $\mathrm{CO}_{2}$ mixing in soils reflect one-dimensional Fickian diffusion (various; [1, 2]). Below a characteristic depth, both modelled and observed to be $>30 \mathrm{~cm}$, soil isotopic $\mathrm{CO}_{2}$ and $\delta^{13} \mathrm{C}_{\text {carb }}$ values should be in isotopic equilibrium. Figure 3 illustrates this reaction pathway, along with the processes responsible for the observed fractionations. For pedogenic carbonates formed prior to $\sim 30 \mathrm{Ma}$ ago when $\mathrm{C}_{4}$ photosynthesis first evolved [29], they all should reflect the distribution on the left-hand column, which depicts plants using the $\mathrm{C}_{3}$ photosynthetic pathway. More recent carbonates are more complicated and could reflect either a pure $\mathrm{C}_{3}$ ecosystem, a mixed $\mathrm{C}_{3}-\mathrm{C}_{4}$ ecosystem, or for the last $\sim 8 \mathrm{Ma}$, potentially a nearly pure $\mathrm{C}_{4}$ ecosystem.

For paleosols that have both carbonates and organic matter, it should be possible to demonstrate whether they have formed in isotopic equilibrium. Based upon the theoretical framework in Figure 3, that relationship should be as follows:

$$
\Delta^{13} \mathrm{C}=\delta^{13} \mathrm{C}_{\mathrm{carb}}-\delta^{13} \mathrm{C}_{\text {org }} \approx+15 \% \text { o. }
$$

Soils that have formed in $\mathrm{C}$ isotope equilibrium should also be in $\mathrm{O}$ isotope equilibrium; thus, $\Delta^{13} \mathrm{C}$ can be used as a screening tool to determine which $\delta^{18} \mathrm{O}_{\text {carb }}$ values can be reliably interpreted.

\section{Results}

Figure 4 shows $\delta^{13} \mathrm{C}_{\text {org }}$ as a function of depth for the five Guvo soil series pits. Each pit is most negative at the surface and reaches a characteristic equilibrium value below a depth of $20 \mathrm{~cm}$. This is consistent with Fickian diffusion as described in Cerling's [2] theoretical framework as well as 


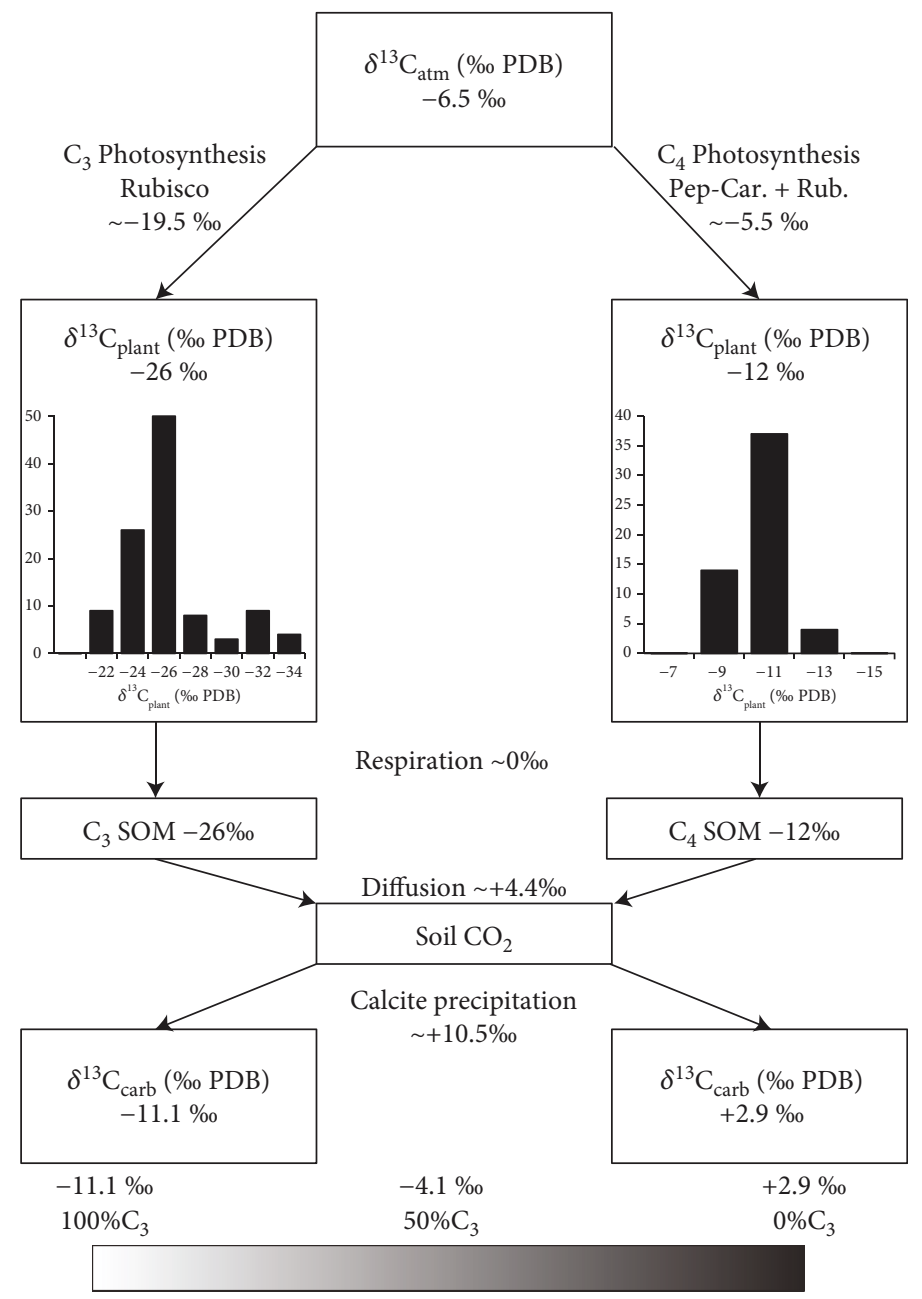

FIgURE 3: Carbon isotope interpretation framework. This figure (design modified from Koch (1998)) shows the hypothetical C isotopic fractionation pathways for plants using both the $\mathrm{C}_{3}$ and $\mathrm{C}_{4}$ photosynthetic pathways in a preindustrial world. The burning of fossil fuels has shifted $\delta^{13} \mathrm{C}_{\mathrm{atm}}$ by $>-1.5 \%$ since 1850 . Distributions of typical modern $\mathrm{C}_{3}(n=109)$ and $\mathrm{C}_{4}(n=55) \delta^{13} \mathrm{C}_{\text {plant }}$ values are from Cerling and Harris [48] and have been modified from the publication by $+1.5 \%$ o to reflect a preindustrial $\delta^{13} \mathrm{C}_{\text {atm }}$ value of $-6.5 \%$. While there is some minor temperature dependence in the $\mathrm{C}$ isotope fraction factor between $\mathrm{CO}_{2}$ and calcite [41], based upon the prevailing theoretical groundwork, $\delta^{13} \mathrm{C}_{\text {carb }}$ values should be $\sim+14.9 \%$ relative to their coexisting soil organic matter (SOM). This relationship is empirically verified in Figure 5.

observed in the studies of in situ measurements of soil gas $\delta^{13} \mathrm{C}$ and coexisting $\delta^{13} \mathrm{C}_{\text {org }}[1,2,25]$.

Measured $\delta{ }^{13} \mathrm{C}_{\text {carb }}$ values for the Guvo soil series ranged from -4.0 to $-6.2 \%$, and standard deviations of replicate analyses of multiple nodules from the same pit ranged from $\pm 0.19 \%$ o to $\pm 0.43 \%$, with a mean of $\pm 0.33 \%$. $\Delta^{13} \mathrm{C}$ ranged from 16.5 to 17.8 . Measured $\delta^{13} \mathrm{C}_{\text {carb }}$ values for the Delthorny soil series ranged from -2.8 to $-4.8 \%$, and standard deviations of replicate analyses of multiple nodules from the same pit ranged from $\pm 0.19 \%$ o to $\pm 0.58 \%$, with a mean of $\pm 0.42 \%$. $\Delta{ }^{13} \mathrm{C}$ ranged from 16.2 to 17.1 .

Figure 5 plots $\delta^{13} \mathrm{C}_{\text {carb }}$ versus $\delta^{13} \mathrm{C}_{\text {org }}$ for each of the nine soil pits as well as the data from two-component calcite soils that were previously published by Tabor et al. [6] from California sites with a Mediterranean climate (winter-wet) and from Cerling and Quade [25] from a variety of western US and Midwestern US sites that reflect an array of precipitation regimes, including both monsoonal and continental (summer-wet) sites. Regardless of the climatic moisture regime, there is a strong correlation $(r=0.96)$ between $\delta^{13} \mathrm{C}_{\text {carb }}$ and $\delta^{13} \mathrm{C}_{\text {org }}$ that is highly significant $\left(p<10^{-26}\right)$. The empirically derived $\Delta^{13} \mathrm{C}$ value is $+15.3 \%$ (i.e., intercept in Figure 5), which closely matches the theoretical $\Delta^{13} \mathrm{C}$ value given in equation (1). The mean $\Delta^{13} \mathrm{C}$ value for all 51 soils is $+15.6 \pm 1.1(1 \sigma)$, which also closely matches equation (1), and will be used as the threshold for equilibrium herein.

\section{Discussion}

4.1. Interpreting Nonequilibrium $\Delta^{13} \mathrm{C}$ Values. Cotton et al. [26] used $\delta^{13} \mathrm{C}_{\text {org }}$ and phytoliths (fossil plant biosilica) to reconstruct the proportion of $\mathrm{C}_{4}$ plants present in southwestern Montana during the late-middle Miocene $(\sim 10.2-8.9 \mathrm{Ma}$ ago), with both types of proxies indicating up to $20 \% \mathrm{C}_{4}$. However, pedogenic carbonates from the same stratigraphic section indicated up to $50 \% \mathrm{C}_{4}$ plants and had $\delta^{18} \mathrm{O}_{\text {carb }}$ values 


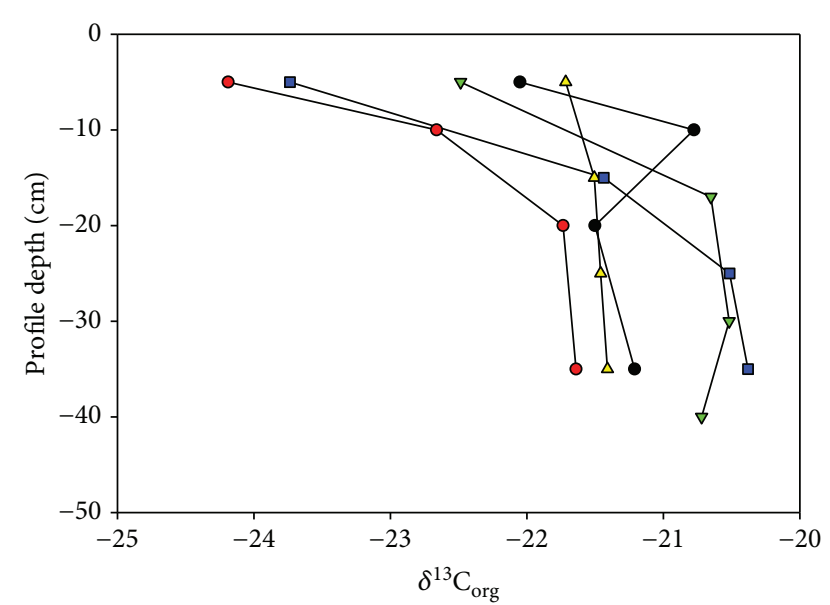

FIGURE 4: Individual soil pit $\delta^{13} \mathrm{C}_{\text {org }}$ depth profiles of five Guvo Soil Series soils. Differences in surface $\delta^{13} \mathrm{C}_{\text {org }}$ and $\delta^{13} \mathrm{C}_{\text {org }}$ at depth reflect differences in the overlying vegetation, but each of the five profiles becomes asymptotic below $\sim 20 \mathrm{~cm}$ in the profile, so $\delta^{13} \mathrm{C}_{\text {carb }}$ values from pedogenic carbonates collected below those depths should be in isotopic equilibrium with their coexisting soil organic matter's $\delta^{13} \mathrm{C}_{\text {org }}$ value.

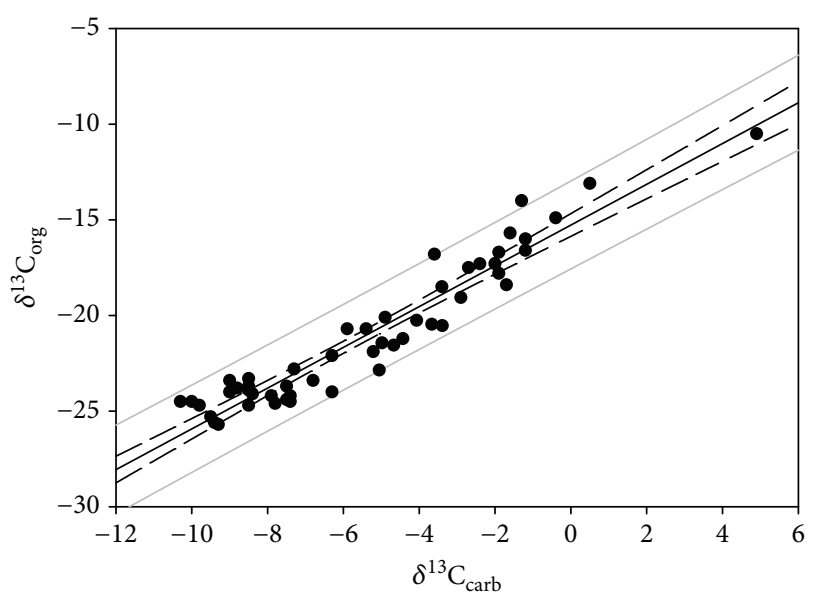

Figure 5: Plot of the relationship between $\delta^{13} \mathrm{C}_{\text {carb }}$ and $\delta^{13} \mathrm{C}_{\text {org }}$ for samples collected $>30 \mathrm{~cm}$ below the soil surface. The results from different regions and different climatic regimes all fall along the same regression line and the calculated $\Delta^{13} \mathrm{C}$ values closely matches the theoretical value given in equation (1). While $\delta^{13} \mathrm{C}_{\text {org }}$ actually drives $\delta^{13} \mathrm{C}_{\text {carb }}$, by convention $\Delta^{13} \mathrm{C}$ is $\delta^{13} \mathrm{C}_{\text {carb }}-\delta^{13} \mathrm{C}_{\text {org }}$, so that is how the data have been regressed here. The solid black line represents the linear regression, the dashed lines the $95 \%$ confidence interval, and the grey lines the $95 \%$ prediction confidence interval.

ranging from 13.4 to $14.5 \%$ (SMOW), which are indistinguishable from the values in Figure 1 for that time period. Using the empirically defined $\Delta^{13} \mathrm{C}$ value of $+15.6 \pm 1.1$ $(1 \sigma)$, it is possible to determine which of these two vegetation scenarios is most likely to be correct, but also whether the $\delta^{18} \mathrm{O}_{\text {carb }}$ values provide a meaningful constraint on meteoric precipitation. With $\Delta^{13} \mathrm{C}$ values of $18.2-22.4$, all of the pedogenic carbonate values are too positive relative to

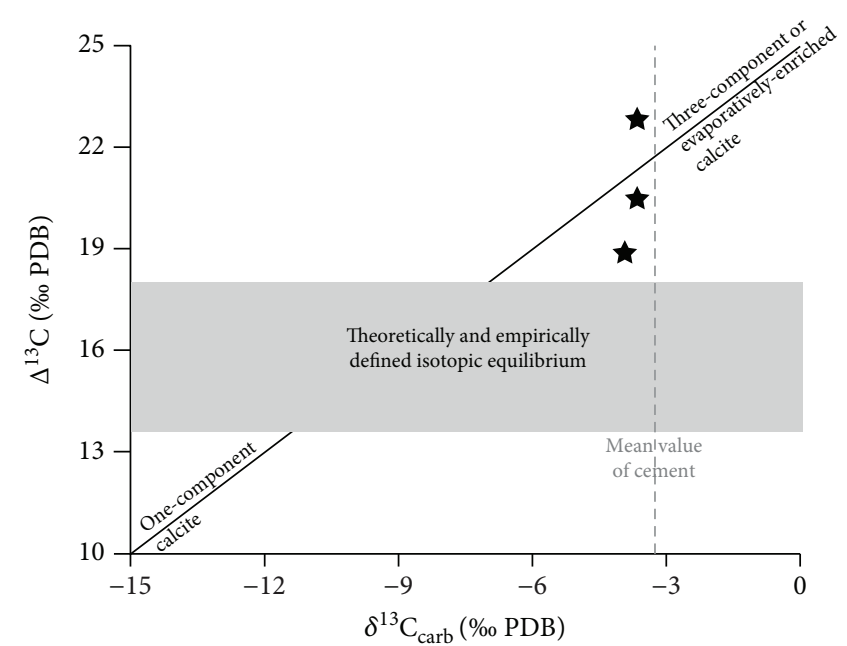

Figure 6: Plot of $\delta^{13} \mathrm{C}_{\text {carb }}$ versus $\Delta^{13} \mathrm{C}$. The grey box spans $\Delta^{13} \mathrm{C}$ values $+13.4-17.84 \%$, which reflects the measured mean $\Delta^{13} \mathrm{C}$ value of $+15.62 \%$ o $\pm 2 \sigma(2.22 \%$ ). The solid black line reflects the slope of all carbonates formed from one-, two-, and threecomponents of $\mathrm{CO}_{2}$ from Tabor et al. [6]. The data from Cotton et al. [26] are given by black stars and represent either carbonates formed under extremely evaporatively enriched conditions in terms of meteoric water or from three-component $\mathrm{CO}_{2}$. In this case, because the entire stratigraphic section is calcite-cemented (grey dashed line; $\delta^{13} \mathrm{C}_{\text {carb }}=-3.2 \pm 0.2 \%$ ) and the calcite cement is isotopic indistinguishable from the pedogenic carbonates, one would conclude that the pedogenic carbonates reflect this inheritance or recrystallization.

their coexisting organic matter to be considered in equilibrium (Figure 6) for the framework that is established here. Therefore, the pedogenic carbonate-based paleovegetation results cannot be considered viable, and the $\delta^{18} \mathrm{O}_{\text {carb }}$ values are unlikely to reflect meteoric precipitation. Indeed, as those authors noted, the $\delta^{18} \mathrm{O}_{\text {carb }}$ values were indistinguishable between the pedogenic carbonate nodules and interstitial cements from the same section (Figure 6). However, in the absence of that information, the same conclusion could be drawn using $\Delta^{13} \mathrm{C}$ values to screen for equilibrium (Figure 6).

4.2. Screening $\delta^{18} \mathrm{O}_{\text {carb }}$ Values Using $\Delta^{13} C$. Returning to Figure 2, the open question was which, if any, of the pedogenic carbonate $\delta^{18} \mathrm{O}_{\text {carb }}$ values could be used from the Wasatch Formation paleosols $[23,28,30]$ to determine paleoelevation. Measured $\Delta{ }^{13} \mathrm{C}$ values along the single paleosol transect ranged from 12.4-19.1\%o and were accompanied by $\delta^{18} \mathrm{O}_{\text {carb }}$ values that ranged from 18.5-26.3\%o (SMOW). Using the empirically determined $\Delta^{13} \mathrm{C}$ value of $+15.6 \pm 1.1$ $(1 \sigma)$, it is clear that only one of the four paleosol profiles from the lateral transect was formed in isotopic equilibrium (Figure 2). In this case, paleosol also corresponds to the most geologically reasonable scenario, namely, of little to no uplift between the closely separated (stratigraphically speaking) paleosols. Hyland and Sheldon $[23,28]$ noted hydromorphic features locally along the transect that were confirmed by rock magnetic properties as likely reflecting localized ponding or a water table that was near to the surface of soils at least 


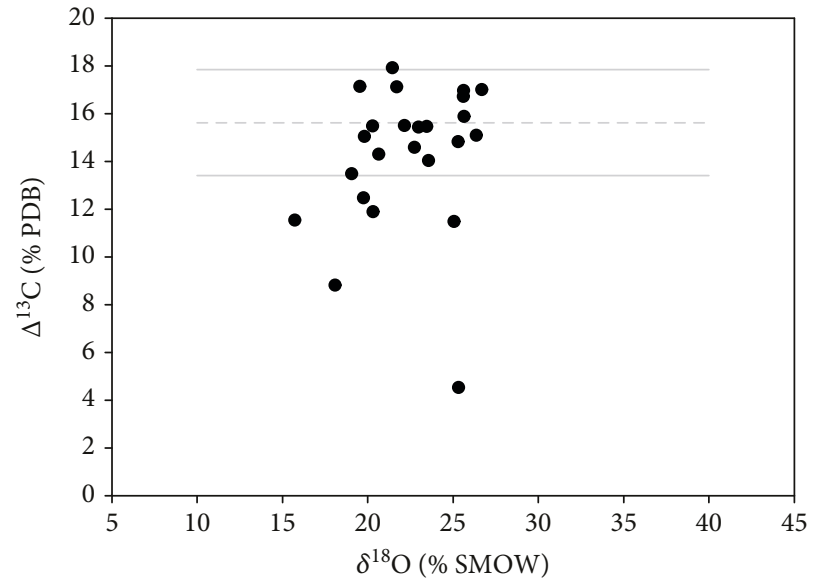

(a)

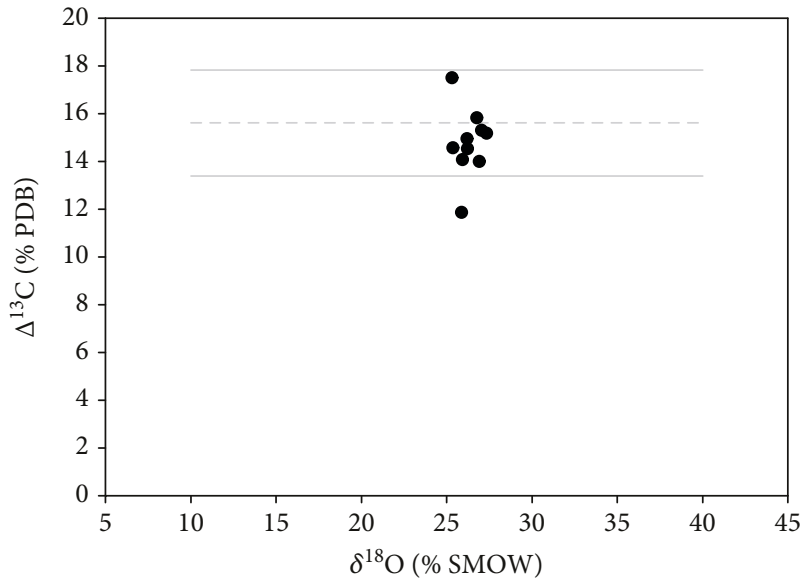

(b)

Figure 7: Plots of $\delta^{18} \mathrm{O}_{\text {carb }}$ versus $\Delta^{13} \mathrm{C}$. (a) This panel shows data from Hyland and Sheldon [28]. Using the $\Delta^{13} \mathrm{C}$ screening criteria outlined in the text, 18 of 24 carbonates formed in equilibrium. By removing the nonequilibrium carbonates from consideration, the range of $\delta^{18} \mathrm{O}_{\text {carb }}$ values drops to $\sim 6.5 \%$ o from $\sim 11 \%$ o. Using the global $\delta^{18}$ O lapse rate of Poage and Chamberlain [18], this would reflect a difference of $\sim 1.6 \mathrm{~km}$ between the estimates of paleoelevation. (b) This panel shows the data from Gutierrez and Sheldon [27]. Using the $\Delta^{13} \mathrm{C}$ screening criteria outlined in the text, nine of ten carbonates formed in equilibrium. The dashed line in both panels represents the empirically observed mean $\Delta^{13} \mathrm{C}$ value of $+15.62 \%$; the solid lines represent $\pm 2 \sigma(2.22 \%)$.

seasonally during their formation. Transect positions with evidence for hydromorphy correspond to both of the $\Delta^{13} \mathrm{C}$ values that fall below the $\pm 2 \sigma$ envelope around the empirically derived equilibrium value. This is consistent with Tabor et al.'s [6] observations of the effects of water-logging on modern soils and with $\delta^{13} C_{\text {carb }}$ values that reflect onecomponent calcite. Overall, 18 of 24 sets of paired organic matter-pedogenic carbonate measurements in the main vertical section of Hyland and Sheldon [28] were formed in isotopic equilibrium (Figure 7(a)). By screening out the nonequilibrium values, the maximum range in $\delta^{18} \mathrm{O}_{\text {carb }}$ values drops from $\sim 11 \%$ o to $\sim 6.5 \%$, and the mean $\delta^{18} \mathrm{O}_{\text {carb }}$ value increased to $\sim 22.9 \%$ o from $\sim 22.4 \%$. Using the global $\delta^{18} \mathrm{O}$ lapse rate of Poage and Chamberlain [18], the range difference would reflect a difference of $\sim 1.6 \mathrm{~km}$ between the estimates of paleoelevation, and the shift in mean would reflect a difference of $\sim 0.2 \mathrm{~km}$.

Based upon the close match of theoretical equilibrium framework and the empirical observations, and the additional observations available at both of these sites that confirm the conditions under which nonequilibrium fractionation is observed, I conclude that measuring $\Delta^{13} \mathrm{C}$ values provides a powerful screening tool for understanding $\delta^{18} \mathrm{O}_{\text {carb }}$ values. Recognizing samples that are out of equilibrium will make it possible to refine the interpretation of samples that are in equilibrium and should substantially reduce the potential uncertainty in paleoaltimetry studies.

There are other applications where paleosols with nonequilibrium $\Delta^{13} \mathrm{C}$ values can provide valuable insights into soil productivity (e.g., [4]), soil drainage as outlined above (e.g., [6]), or to reconstruct MAP in arid systems [31]. Accompanying $\delta^{18} \mathrm{O}$ values from paleosols with nonequilibrium $\Delta^{13} \mathrm{C}$ values are still useful for understanding diagenetic alteration (see below) and mixing of multiple pedogenic and postburial water sources.
4.3. Validating the Meaning of $\delta^{18} \mathrm{O}_{\text {carb }}$ Values. To validate that $\delta^{18} \mathrm{O}_{\text {carb }}$ values reflect source water $\delta^{18} \mathrm{O}$ compositions, an ideal dataset would represent pedogenic carbonates that formed very close to their meteoric water source and that the meteoric water source would be relatively homogeneous throughout the year. Gutierrez and Sheldon [27] reported on a series of paleosols from the Upper Jurassic Vega Formation of Spain. The Vega Formation represents a dinosaur footprint-bearing floodplain environment; it is underlain by the ammonite-bearing shale-limestone couplets of the Rodiles Formation and is overlain by the mixed estuarine deposition of the Tereñes Formation [32]. Thus, the Vega Formation is unambiguously near sea level and near its meteoric water source. Among the paleosols with co-occurring organic matter, nine of ten are in isotopic equilibrium when screened using $\Delta^{13} \mathrm{C}$ (Figure $\left.7(\mathrm{~b})\right)$ and have a mean $\delta^{18} \mathrm{O}_{\text {carb }}$ value of $26.25 \pm 0.65 \%$ o $(1 \sigma)$. Using the reconstructed MAT of $13 \pm 4^{\circ} \mathrm{C}$ [27] and measured $\delta^{18} \mathrm{O}_{\text {carb }}$ value, the meteoric water $\delta^{18} \mathrm{O}$ composition was $-4.8 \pm 0.9 \%$ (Figure 8; height of grey box includes $\pm 2 \sigma$ ). Pedogenic carbonates typically form seasonally, with the duration of moisture deficit necessary and timing of first annual moisture deficit necessary to form pedogenic carbonate both dependent on the climatic regime (e.g., [5, 33-35]), so they could potentially form over anywhere from less than a month to the whole year depending upon the local conditions. Based upon OIPC estimates for the site today, the mean annual $\delta^{18} \mathrm{O}_{\text {water }}$ is $-6.3 \%$ and seasonally adjusted (i.e., March-September, representing the most likely season of carbonate formation; [5]) mean $\delta^{18} \mathrm{O}_{\text {water }}$ is $-4.1 \pm 2.3 \%$ (Figure 8). The mean annual value is within the $2 \sigma$ uncertainty of the reconstructed value and the seasonally adjusted predicted range of precipitation $\delta^{18} \mathrm{O}$ encompasses the reconstructed value (Figure 8), suggesting that regardless of which metric is more representative of Jurassic meteoric precipitation at the site, the pedogenic 


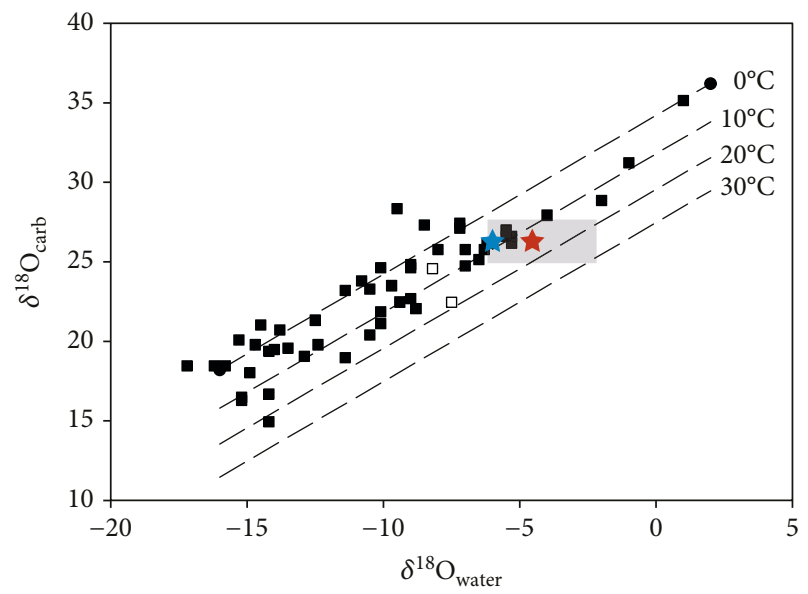

Figure 8: Plot of $\delta^{18} \mathrm{O}_{\text {carb }}$ versus $\delta^{18} \mathrm{O}$ of meteoric water for each soil shown in Figure 5. Isotherms have been calculated using Kim and O'Neil [49]. Black squares are the data from Cerling and Quade [25], and white squares are the multisoil pit means for Arizona (this study). The red star represents the mean measured $\delta^{18} \mathrm{O}_{\text {carb }}$ value for pedogenic carbonates from Gutierrez and Sheldon [27]; $\delta^{18} \mathrm{O}_{\text {water }}$ was based upon an independently reconstructed MAT of $13^{\circ} \mathrm{C}$ for the paleosols and a fractionation factor from Kim and O'Neil [49]. The blue star is the interpolated mean annual $\delta^{18} \mathrm{O}_{\text {water }}$ value from the OIPC [24]. The grey box shows the seasonally adjusted (March-September) modern range of $\delta^{18} \mathrm{O}_{\text {water }}$ values for the present day latitude and longitude. For modern soil sites without direct measurements of the $\delta^{18} \mathrm{O}$ of meteoric water (white squares), the OIPC was used to calculate the value.

carbonate $\delta^{18} \mathrm{O}_{\text {carb }}$ values clearly reflect their source water. Furthermore, the $\delta^{18} \mathrm{O}_{\text {carb }}$ data exhibit low variability (i.e., low $\sigma$ ) throughout the stratigraphic section indicating little variation in the source moisture composition, which is consistent with Gutierrez and Sheldon [27] paleoclimatic and paleoenvironmental reconstruction based upon independent paleoclimatic proxies for MAT and MAP from major element oxide transfer functions that indicated relatively constant paleoclimatic conditions.

4.4. Implications for Montana Paleoelevation Record. As outlined above, one of the goals herein is to provide better constraints on long-term $\delta{ }^{18} \mathrm{O}_{\text {carb }}$ records that have been used to reconstruct paleoaltimetry and paleoelevation. Figure 1 shows a large dataset of pedogenic carbonate $\delta^{18} \mathrm{O}_{\text {carb }}$ values from southwestern Montana [22] that can be reassessed in light of the new $\Delta^{13} \mathrm{C}$ criterion for isotopic equilibrium. For most of the sites in that database, only $\delta^{13} \mathrm{C}_{\text {carb }}$ values were published, but independent constraints from paleovegetation studies can be used to constrain $\delta^{13} \mathrm{C}_{\text {org. }}$. While differences in the value of $\delta^{13} \mathrm{C}_{\mathrm{atm}}$ would change the absolute values expected for $\mathrm{C}_{3}$ plants a la Figure 3, reconstructions of Cenozoic $\delta^{13} \mathrm{C}_{\text {atm }}$ are typically centered around $-6 \%$ and show relatively little variability [36], and Retallack [37] reconstructed long-term climatic stability in the region, so the expected $\mathrm{C}_{3}$ plant $\delta^{13} \mathrm{C}_{\text {org }}$ value can be considered relatively constant. As discussed in
Interpretational Framework section, prior to the evolution of $\mathrm{C}_{4}$ plants, only the empirical $\Delta^{13} \mathrm{C}$ criterion is needed to screen for isotopic equilibrium. However, following the evolution of $\mathrm{C}_{4}$ plants, $\delta^{13} \mathrm{C}_{\text {org }}$ and $\delta^{13} \mathrm{C}_{\text {carb }}$ would both be shifted toward more positive values if any $\mathrm{C}_{4}$ plants were present. Based upon the studies of phytoliths [38] and paleosol C isotopes $[26,39,40], \mathrm{C}_{4}$ plants comprised up to $20 \%$ of ecosystems in southwestern Montana for the whole of the Neogene. To be conservative then, all pre-24 Ma pedogenic carbonates are assumed to have formed in a pure- $\mathrm{C}_{3}$ ecosystem, and all post- $24 \mathrm{Ma}$ pedogenic carbonates are assumed to have formed in an ecosystem with $20 \% \mathrm{C}_{4}$ plants. Even using this relaxed criterion, just 29 of 308 paleosols described by Chamberlain et al. [22] formed in isotopic equilibrium (Figure $9(\mathrm{a})$ ). If one allows for $\sim 50 \%$ more $\mathrm{C}_{4}$ plants than were observed in the previous studies or for plant water stress equivalent to semiarid conditions and relaxes the high end uncertainty in $\Delta^{13} \mathrm{C}$ by another $1.5 \%$ (alternatively, this could be thought of as incorporating $>+3 \sigma$ ), then still just 73 of the paleosols were formed in isotopic equilibrium. Looking at just those culled data (Figure 9(b)), there is no discernible pattern in $\delta^{18} \mathrm{O}_{\text {carb }}$ for any significant elevation change over the past $\sim 40 \mathrm{Ma}$. Instead, the data would be consistent with little or no post-Laramide uplift of the region. At the same time, there are only two pre-24 Ma data points that represent equilibrium conditions, so a more conservative conclusion would be that while there could have been a significant uplift event between 50 and $30 \mathrm{Ma}$ ago, the $\delta^{18} \mathrm{O}_{\text {carb }}$ record can neither support nor exclude that possibility, so other types of data will be necessary to confirm that hypothesis.

Could Cenozoic climate change be masking an elevation change? Warmer climatic conditions would make $\varepsilon_{\mathrm{CO} 2 \text {-calcite }}$ smaller than the $+10.5 \%$ o given in Figure 3 [41], which would lower the expected $\Delta^{13} \mathrm{C}$ below the empirically observed value. Rather than increasing the range of potential isotopic equilibrium values, this would actually reduce the mean and range further, indicating that even fewer of the pedogenic carbonates from Montana formed in isotopic equilibrium. Similarly, even if $\delta^{13} \mathrm{C}_{\mathrm{atm}}$ was closer to one of the extreme ends of its geologically plausible range of -5 to $-6.5 \%$, for any additional soils that could represent equilibrium conditions, an equal number would be lost.

Two plausible explanations exist to explain why so few of the pedogenic carbonates from Montana appear to have formed in isotopic equilibrium: (1) significant evaporative enrichment and water stress or (2) diagenetic alteration. While quantitative paleoclimatic reconstructions do not exist for the entirety of the record, for at least the past $40 \mathrm{Ma}$, southwestern Montana has fluctuated within a relative narrow range of subhumid to semiarid conditions [37], and prior to the Miocene, warm-wet indicator plants such as palms and gingers are frequently recorded by phytolith assemblages [38, 42], with drier-adapted vegetation such as grasses emerging to dominance from the Miocene onward. Thus, the part of the record in which isotopic disequilibrium due to water stress is most plausible as an explanation is actually the part of the record where the pedogenic carbonates instead reflect isotopic equilibrium most frequently, so this 


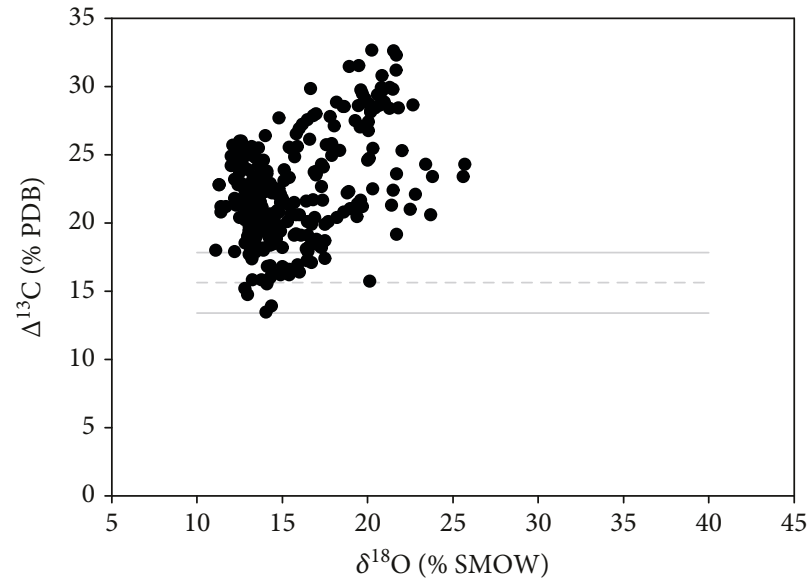

(a)

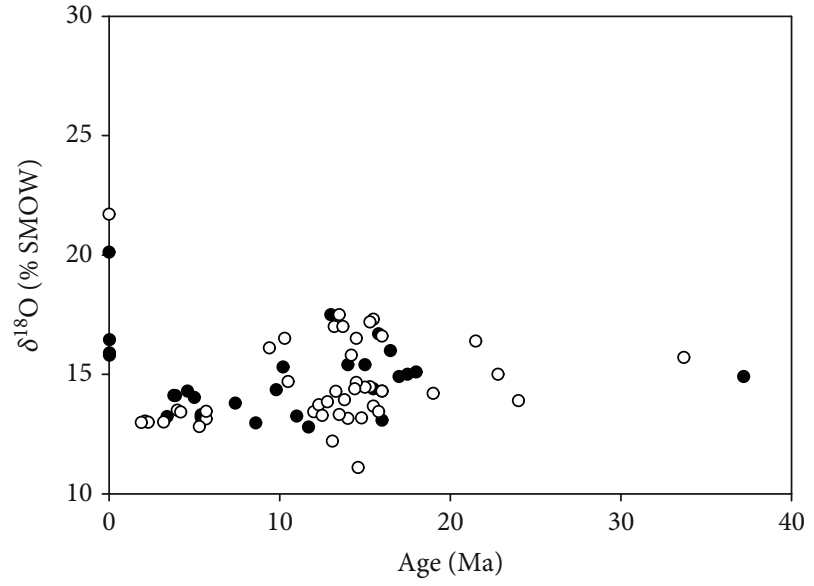

(b)

Figure 9: Montana paleoelevation revisited. (a) Plot of $\delta^{18} \mathrm{O}_{\text {carb }}$ versus $\Delta^{13} \mathrm{C}$ for the past $75 \mathrm{Ma}$ in southwestern Montana (data from [22]). Based upon the theoretical and empirical constraints from Figures 3 and 5, the data set has been literally decimated, with only 29 of 308 ( $9.4 \%$ ) pedogenic carbonates were formed in isotopic equilibrium and most of the data are extremely out of equilibrium (note the scale change versus Figure 8). (b) Plot of the remaining pedogenic carbonates that formed in isotopic equilibrium (black circles). Almost all of the structure in the dataset present in Figure 1 is gone. If one allows for evaporative due to water stress on the plants producing the organic matter of $+1.5 \%$ (see text for discussion), the white circles would also represent equilibrium conditions. However, in both cases, little or no change in elevation is indicated by $\delta^{18} \mathrm{O}_{\text {carb }}$ values, and there are essentially no pre-Miocene data points that can be used to assess the previously identified elevation change between 50 and $30 \mathrm{Ma}$ ago identified by Chamberlain et al. [22].

explanation is unlikely to be responsible for the dearth of reliable pre-24 Ma data. The second explanation, burial diagenesis, is more plausible. Given that the Laramide Orogeny occurred from roughly 70 to $40 \mathrm{Ma}$ ago (e.g., [43]) throughout western North America and that pre-70 Ma strata include numerous formations associated with the Western Interior Seaway, much of the present day topographic relief was developed during the part of the Montana carbonate record that exhibits substantial disequilibrium. The wide spread in $\delta^{18} \mathrm{O}_{\text {carb }}$ values, especially from 50 to $40 \mathrm{Ma}$ ago (Figure 1) likely reflects mixing of both meteoric and crustal diagenetic water sources. In that sense, the large observed shifts in $\delta^{18} \mathrm{O}_{\text {carb }}$ values between 50 and $30 \mathrm{Ma}$ ago could represent exhumation and unroofing leading to mixing of diagenetic water sources, even if the values themselves cannot be used quantitatively to determine absolute paleoelevation changes.

4.5. Recommendations for Future Paleoaltimetry Studies. In studying modern pedogenic carbonates, Cerling and Quade [25] noted that in some cases, pedogenic carbonates had higher $\delta^{18} \mathrm{O}_{\text {carb }}$ values than would be predicted from $\delta^{18} \mathrm{O}_{\text {water }}$ values alone. They attributed this effect on $\delta^{18} \mathrm{O}_{\text {carb }}$ values to localized evaporative enrichment of the source water, which has subsequently been identified in other modern studies as well (reviewed by Quade et al. [15]). Breecker et al. [1] used observations of instrumented modern soils in New Mexico to argue for a spring to warm-season bias in pedogenic carbonate formation, and Passey et al. [44] used clumped isotopes to confirm a warm season bias for soils from East Africa. Quade et al. [15] proposed that this observation of warm-season bias reflected summertime ground heating above air temperatures. However, Tabor et al. [6] found that under some conditions, pedogenic carbonate stable oxygen isotope values did not reflect a warm season bias and that the season of moisture availability was more important than the time of the highest temperatures. Gallagher et al. [5] recently extended this approach using a combination of clumped isotope data and hydrological cycle modeling to show that pedogenic carbonate isotopic compositions could reflect anything from sub-MAT to warm seasonal bias, depending on the seasonality of the moisture regime and amount of vegetative covering, which in turn impacts ground heating. In none of these studies though, was the extreme spread observed in $\delta^{18} \mathrm{O}_{\text {carb }}$ values from the Montana record (Figure 1), so as discussed above, extensive diagenetic alteration is the only plausible explanation. This may be true of many pedogenic carbonate records that have been used for paleoaltimetry purposes and where extremely wide spreads in $\delta^{18} \mathrm{O}_{\text {carb }}$ values are observed. Many of those studies could be usefully reappraised using $\Delta^{13} \mathrm{C}$ to screen for carbonates that formed in isotopic equilibrium.

Based upon the results in this study and other recent studies, it is appropriate to propose revised guidelines for future paleoaltimetry studies that include collection of both vertical stratigraphic sections and lateral transects [23], description and classification of paleosol type [4, 45], collection of at least three nodules per horizon and petrographic screening of nodules for micrite rather than spar [26], collection of at least one independent proxy for paleoclimate or paleovegetation [46], and screening $\delta^{18} \mathrm{O}_{\text {carb }}$ values using $\Delta^{13} \mathrm{C}$ measured for each paleosol (this study). While this approach will necessitate significantly more work than some previous studies have undertaken, it will minimize uncertainty in paleoelevation reconstructions 
and make it possible to explain both carbonates formed in equilibrium and those that are out of equilibrium mechanistically.

\section{Conclusions}

Many studies that attempt to reconstruct paleoelevations either to understand paleotectonic or paleo-geodynamic changes in the geologic record rely on pedogenic carbonates. However, many of those carbonate records have $\delta^{18} \mathrm{O}_{\text {carb }}$ variability that exceeds reasonable elevation changes or which would conflict with independent lines of evidence. Herein, I have proposed that carbon isotope equilibrium as defined by $\Delta^{13} \mathrm{C}$ can be a useful screening tool for $\delta^{18} \mathrm{O}_{\text {carb }}$ values. Case studies from the Miocene and Eocene where there are independent constraints on the paleoenvironment were used to establish evidence of both equilibrium formation and disequilibrium, and Jurassic paleosols were used to establish that pedogenic carbonates in the geologic record should reflect their meteoric source water just as they do in modern soils. Using the new screening tool, a long-term record of $\delta^{18} \mathrm{O}_{\text {carb }}$ values that has been used to reconstruct paleoelevation and paleotectonic changes in the northern Rocky Mountains of the US was reassessed and $>90 \%$ of the published isotopic analyses do not pass the isotopic equilibrium test. For the samples that do, no significant change in elevation is indicated for the past $24 \mathrm{Ma}$. With virtually all of the pre-32 Ma showing significant alteration, it may be that the signal of uplift is best defined by looking for isotopic disequilibrium. However, this precludes the use of $\delta^{18} \mathrm{O}_{\text {carb }}$ values for quantitative paleoelevation reconstruction. Other previously published records likely need a similar reassessment. Finally, protocols are suggested for future paleoaltimetry studies to overcome many of the challenges that are outlined herein. Future work will endeavor to understand with more clarity the broad departures in $\delta^{18} \mathrm{O}_{\text {carb }}$ variability in the paleosol record as compared to modern systems and to evaluate its potential utility as a chemical proxy of burial environment.

\section{Data Availability}

New data discussed in the paper are available as part of the Supplementary Materials.

\section{Conflicts of Interest}

The author declares that there is no conflict of interest regarding the publication of this paper.

\section{Acknowledgments}

Jen Cotton aided with sample collection and preparation and Lora Wingate with stable isotope analyses. This research was funded by the National Science Foundation (USA) (\#1024535).

\section{Supplementary Materials}

Supplementary materials consist of two supplemental data tables. (Supplementary Materials)

\section{References}

[1] D. O. Breecker, Z. D. Sharp, and L. D. McFadden, "Seasonal bias in the formation and stable isotopic composition of pedogenic carbonate in modern soils from Central New Mexico, USA," Geological Society of America Bulletin, vol. 121, no. 3-4, pp. 630-640, 2009.

[2] T. E. Cerling, "The stable isotopic composition of modern soil carbonate and its relationship to climate," Earth and Planetary Science Letters, vol. 71, no. 2, pp. 229-240, 1984.

[3] D. Royer, "Depth to pedogenic carbonate horizon as a paleoprecipitation indicator?," Geology, vol. 27, no. 12, pp. 1123-1126, 1999.

[4] N. D. Sheldon and N. J. Tabor, "Quantitative paleoenvironmental and paleoclimatic reconstruction using paleosols," Earth-Science Reviews, vol. 95, no. 1-2, pp. 1-52, 2009.

[5] T. M. Gallagher and N. D. Sheldon, "Combining soil water balance and clumped isotopes to understand the nature and timing of pedogenic carbonate formation," Chemical Geology, vol. 435, pp. 79-91, 2016.

[6] N. J. Tabor, S. Myers, E. Gulbranson, and N. D. Rasmussen, "Carbon stable isotope composition of modern calcareous soil profiles in California: implications for $\mathrm{CO}_{2}$ reconstructions from calcareous paleosols," in New Frontiers in Paleopedology and Terrestrial Paleoclimatology, SEPM Special Publications 104, S. G. Driese and L. Nordt, Eds., pp. 17-34, SEPM (Society for Sedimentary Geology), 2013.

[7] J. Quade, T. E. Cerling, and J. R. Bowman, "Development of Asian monsoon revealed by marked ecological shift during the latest Miocene in northern Pakistan," Nature, vol. 342, no. 6246 , pp. 163-166, 1989.

[8] D. O. Breecker, Z. D. Zharp, and L. D. McFadden, "Atmospheric $\mathrm{CO}_{2}$ concentrations during ancient greenhouse climates were similar to those predicted for A.D. 2100," Proceedings of the National Academy of Sciences of the United States of America, vol. 107, no. 2, pp. 576-580, 2010.

[9] T. E. Cerling, "Carbon dioxide in the atmosphere: evidence from Cenozoic and Mesozoic paleosols," American Journal of Science, vol. 291, no. 4, pp. 377-400, 1991.

[10] D. D. Ekart, T. E. Cerling, I. P. Montañez, and N. J. Tabor, "A 400 million year carbon isotope record of pedogenic carbonate: implications for paleoatomospheric carbon dioxide," American Journal of Science, vol. 299, no. 10, pp. 805-827, 1999.

[11] N. J. Tabor and C. J. Yapp, "Coexisting goethite and gibbsite from a high-paleolatitude $\left(55^{\circ} \mathrm{N}\right)$ late Paleocene laterite: concentration and ${ }^{13} \mathrm{C} /{ }^{12} \mathrm{C}$ ratios of occluded $\mathrm{CO}_{2}$ and associated organic matter," Geochimica et Cosmochimica Acta, vol. 69, no. 23, pp. 5495-5510, 2005.

[12] C. J. Yapp and H. Poths, "Carbon isotopes in continental weathering environments and variations in ancient atmospheric $\mathrm{CO}_{2}$ pressure," Earth and Planetary Science Letters, vol. 137, no. 1-4, pp. 71-82, 1996.

[13] N. J. Tabor, I. P. Moñtanez, M. B. Steiner, and D. Schwindt, " $\delta{ }^{13} \mathrm{C}$ values of carbonate nodules across the Permian-Triassic boundary in the Karoo Supergroup (South Africa) reflect a stinking sulfurous swamp, not atmospheric 
$\mathrm{CO}_{2}$," Palaeogeography, Palaeoclimatology, Palaeoecology, vol. 252, no. 1-2, pp. 370-381, 2007.

[14] D. B. Rowley, R. T. Pierrehumbert, and B. S. Currie, "A new approach to stable isotope-based paleoaltimetry: implications for paleoaltimetry and paleohypsometry of the High Himalaya since the late Miocene," Earth and planetary science letters, vol. 188, no. 1-2, pp. 253-268, 2001.

[15] J. Quade, C. Garzione, and J. Eiler, "Paleoelevation reconstruction using pedogenic carbonates," Reviews in Mineralogy and Geochemistry, vol. 66, no. 1, pp. 53-87, 2007.

[16] S. I. Dworkin, L. Nordt, and S. Atchley, "Determining terrestrial paleotemperatures using the oxygen isotopic composition of pedogenic carbonate," Earth and Planetary Science Letters, vol. 237, no. 1-2, pp. 56-68, 2005.

[17] G. H. Roe, "Orographic precipitation," Annual Reviews of Earth and Planetary Sciences, vol. 33, no. 1, pp. 645-671, 2005.

[18] M. A. Poage and C. P. Chamberlain, "Empirical relationships between elevation and the stable isotope composition of precipitation and surface waters: considerations for studies of paleoelevation change," American Journal of Science, vol. 301, no. 1, pp. 1-15, 2001.

[19] C. N. Garzione, D. L. Dettman, J. Quade, P. G. DeCelles, and R. F. Butler, "High times on the Tibetan Plateau: paleoelevation of the Thakkhola graben, Nepal," Geology, vol. 28, no. 4, pp. 339-342, 2000.

[20] C. N. Garzione, J. Quade, P. G. DeCelles, and N. B. English, "Predicting paleoelevation of Tibet and the Himalaya from $\delta 18 \mathrm{O}$ vs. altitude gradients in meteoric water across the Nepal Himalaya," Earth and Planetary Science Letters, vol. 183, no. 1-2, pp. 215-229, 2000.

[21] L. A. Stern and P. M. Blisniuk, "Stable isotope composition of precipitation across the southern Patagonian Andes," Journal of Geophysical Research, vol. 107, no. D23, pp. ACL 3-1-ACL 3-14, 2002.

[22] C. P. Chamberlain, H. T. Mix, A. Mulch et al., "The Cenozoic climatic and topographic evolution of the western North American Cordillera," American Journal of Science, vol. 312, no. 2, pp. 213-262, 2012.

[23] E. G. Hyland and N. D. Sheldon, "Examining the spatial consistency of palaeosol proxies: implications for palaeoclimatic and palaeoenvironmental reconstructions in terrestrial sedimentary basins," Sedimentology, vol. 63, no. 4, pp. 959-971, 2016.

[24] G. J. Bowen, "The online isotopes in precipitation calculator, version 3.1," 2017, March 2018, http://www.waterisotopes.org.

[25] T. E. Cerling and J. Quade, "Stable carbon and oxygen isotopes in soil carbonates," in Continental Indicators of Climate, P. Swart, J. A. McKenzie, and K. C. Lohmann, Eds., vol. 78, pp. 217-231, American Geophysical Union Monograph, Jackson Hole, WY, USA, 1993.

[26] J. M. Cotton, N. D. Sheldon, and C. A. E. Strömberg, "Highresolution isotopic record of $\mathrm{C}_{4}$ photosynthesis in a Miocene grassland," Palaeogeography, Palaeoclimatology, Palaeoecology, vol. 337-338, pp. 88-98, 2012.

[27] K. Gutierrez and N. D. Sheldon, "Paleoenvironmental reconstruction of Jurassic dinosaur habitats of the Vega Formation, Asturias, Spain,” GSA Bulletin, vol. 124, no. 3-4, pp. 596610, 2012.

[28] E. G. Hyland and N. D. Sheldon, "Coupled $\mathrm{CO}_{2}$-climate response during the early Eocene climatic optimum," Palaeogeography, Palaeoclimatology, Palaeoecology, vol. 369, pp. 125135, 2013.
[29] E. J. Edwards, C. P. Osborne, C. A. E. Strömberg, S. A. Smith, and C4 Grasses Consortium, "The origins of $\mathrm{C}_{4}$ grasslands: integrating evolutionary and ecosystem science," Science, vol. 328, no. 5978, pp. 587-591, 2010.

[30] E. G. Hyland, N. D. Sheldon, and M. Fan, “Terrestrial paleoenvironmental reconstructions indicate transient peak warming during the early Eocene climatic optimum," GSA Bulletin, vol. 125, no. 7-8, pp. 1338-1348, 2013.

[31] N. J. Tabor, T. S. Myers, C. A. Sidor, R. M. H. Smith, S. J. Nesbitt, and K. Angielczyk, "Paleosols of the Permian-Triassic: proxies for rainfall, climate change and major changes in terrestrial tetrapod diversity," Journal of Vertebrate Paleontology, vol. 37, Supplement 1, pp. 240-253, 2017.

[32] M. Aurell, G. Meléndez, and F. Olóriz, "Jurassic," in The Geology of Spain, W. Gibbons and T. Moreno, Eds., pp. 213253, The Geological Society (London), Bath (UK), 2002.

[33] L. Burgener, K. W. Huntington, G. D. Hoke et al., "Variations in soil carbonate formation and seasonal bias over $>4 \mathrm{~km}$ of relief in the western Andes $\left(30^{\circ} \mathrm{S}\right)$ revealed by clumped isotope thermometry," Earth and Planetary Science Letters, vol. 441, pp. 188-199, 2016.

[34] A. Licht, J. Quade, A. Kowler et al., "Impact of the North American monsoon on isotope paleoaltimeters: implications for the paleoaltimetry of the American southwest," American Journal of Science, vol. 317, no. 1, pp. 1-33, 2017.

[35] M. C. Ringham, G. D. Hoke, K. W. Huntington, and J. N. Aranibar, "Influence of vegetation type and site-to-site variability on soil carbonate clumped isotope records, Andean piedmont of Central Argentina (32-34 S)," Earth and Planetary Science Letters, vol. 440, pp. 1-11, 2016.

[36] B. J. Tipple, S. R. Meyers, and M. Pagani, "Carbon isotope ratio of Cenozoic $\mathrm{CO}_{2}$ : a comparative evaluation of available geochemical proxies," Paleoceanography, vol. 25, no. 3, article PA3202, 2010.

[37] G. J. Retallack, "Cenozoic paleoclimate on land in North America," Journal of Geology, vol. 115, no. 3, pp. 271294, 2007.

[38] C. A. E. Strömberg, "Decoupled taxonomic radiation and ecological expansion of open-habitat grasses in the Cenozoic of North America," Proceedings of the National Academy of Sciences, vol. 102, no. 34, pp. 11980-11984, 2005.

[39] S. T. Chen, S. Y. Smith, N. D. Sheldon, and C. A. E. Strömberg, "Regional-scale variability in the spread of grasslands in the late Miocene," Palaeogeography, Palaeoclimatology, Palaeoecology, vol. 437, pp. 42-52, 2015.

[40] E. B. Harris, C. A. E. Strömberg, N. D. Sheldon, S. Y. Smith, and D. A. Vilhena, "Vegetation response during the lead-up to the middle Miocene warming event in the Northern Rocky Mountains, USA," Palaeogeography, Palaeoclimatology, Palaeoecology, vol. 485, pp. 401-415, 2017.

[41] C. S. Romanek, E. L. Grossman, and J. W. Morse, "Carbon isotopic fractionation in synthetic aragonite and calcite: effects of temperature and precipitation rate," Geochimica et Cosmochimica Acta, vol. 56, no. 1, pp. 419-430, 1992.

[42] L. A. Miller, S. Y. Smith, N. D. Sheldon, and C. A. E. Strömberg, "Eocene vegetation and ecosystem fluctuations inferred from a high-resolution phytolith record," Geological Society of America Bulletin, vol. 124, no. 9-10, pp. 15771589, 2012.

[43] E. Humphreys, E. Hessler, K. Dueker, G. L. Farmer, E. Ersley, and T. Atwater, "How Laramide-age hydration of North 
American lithosphere by the Farallon slab controlled subsequent activity in the western United States," International Geology Review, vol. 45, no. 7, pp. 575-595, 2003.

[44] B. H. Passey, N. E. Levin, T. E. Cerling, F. H. Brown, and J. M. Eiler, "High-temperature environments of human evolution in East Africa based on bond ordering in paleosol carbonates," Proceedings of the National Academy of Science, vol. 107, no. 25, pp. 11245-11249, 2010.

[45] G. H. Mack, W. C. James, and H. C. Monger, "Classification of paleosols," Geological Society of America Bulletin, vol. 105, no. 2, pp. 129-136, 1993.

[46] S. Y. Smith, S. R. Manchester, B. Samant et al., "Integrating paleobotanical, paleosol, and stratigraphic data to study critical transitions: a case study from the late Cretaceous-Paleocene of India," in Earth-Life Transitions: Paleobiology in the Context of Earth System Evolution, P. D. Polly, J. J. Head, and D. L. Fox, Eds., pp. 137-166, The Paleontological Society Papers 21, 2015.

[47] E. B. Harris, C. A. E. Strömberg, N. D. Sheldon, S. Y. Smith, and M. Ibañez-Mejia, "Revised chronostratigraphy and biostratigraphy of the early-middle Miocene Railroad Canyon section of Central-Eastern Idaho, USA," GSA Bulletin, vol. 129, no. 9-10, pp. 1241-1251, 2017.

[48] T. E. Cerling and J. M. Harris, "Carbon isotope fractionation between diet and bioapatite in ungulate mammals and implications for ecological and paleoecological studies," Oecologia, vol. 120, no. 3, pp. 347-363, 1999.

[49] S.-T. Kim and J. R. O'Neil, "Equilibrium and nonequilibrium oxygen isotope effects in synthetic carbonates," Geochemica et Cosmochimica Acta, vol. 61, no. 16, pp. 3461-3475, 1997. 

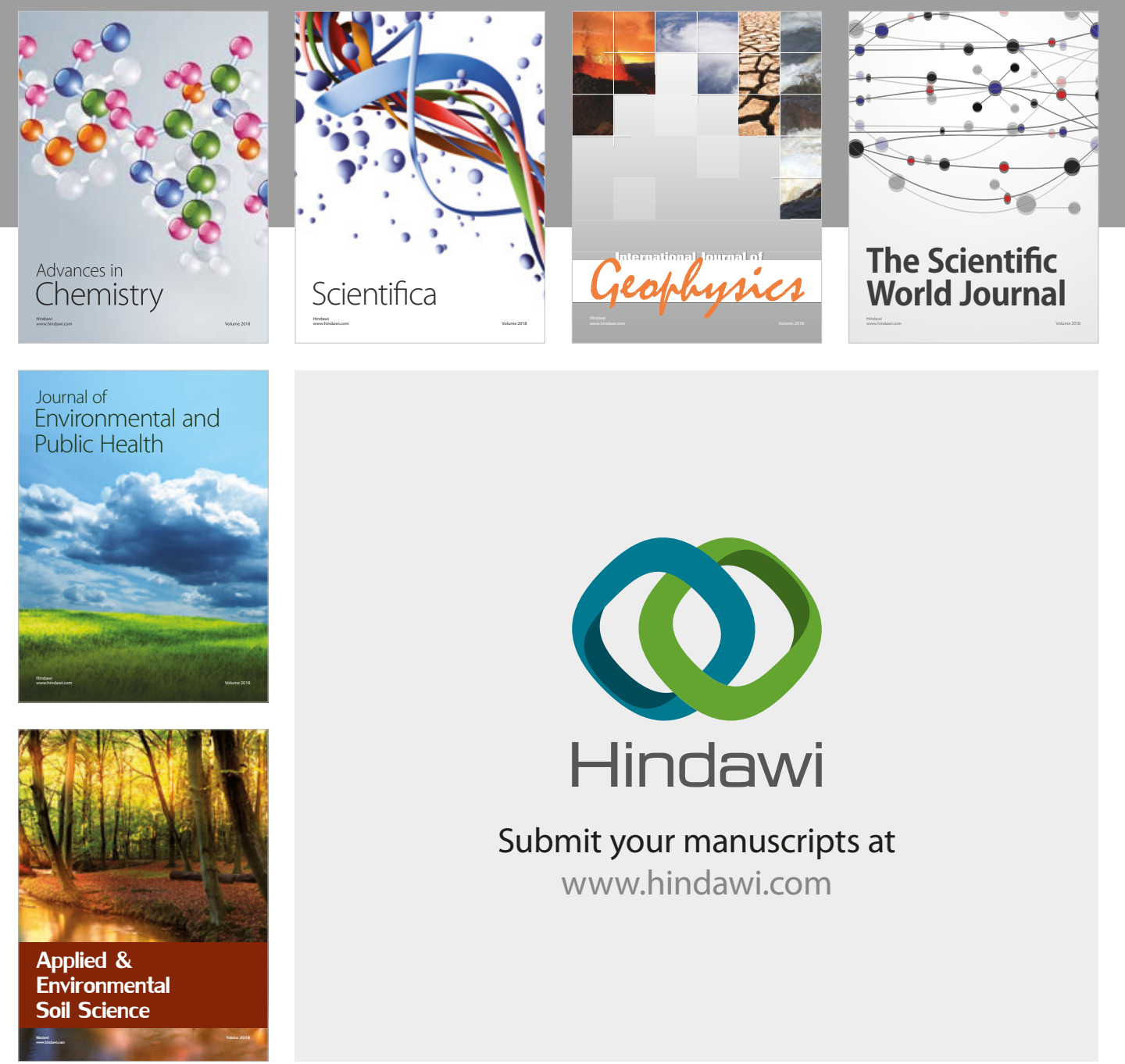

The Scientific

\section{World Journal}
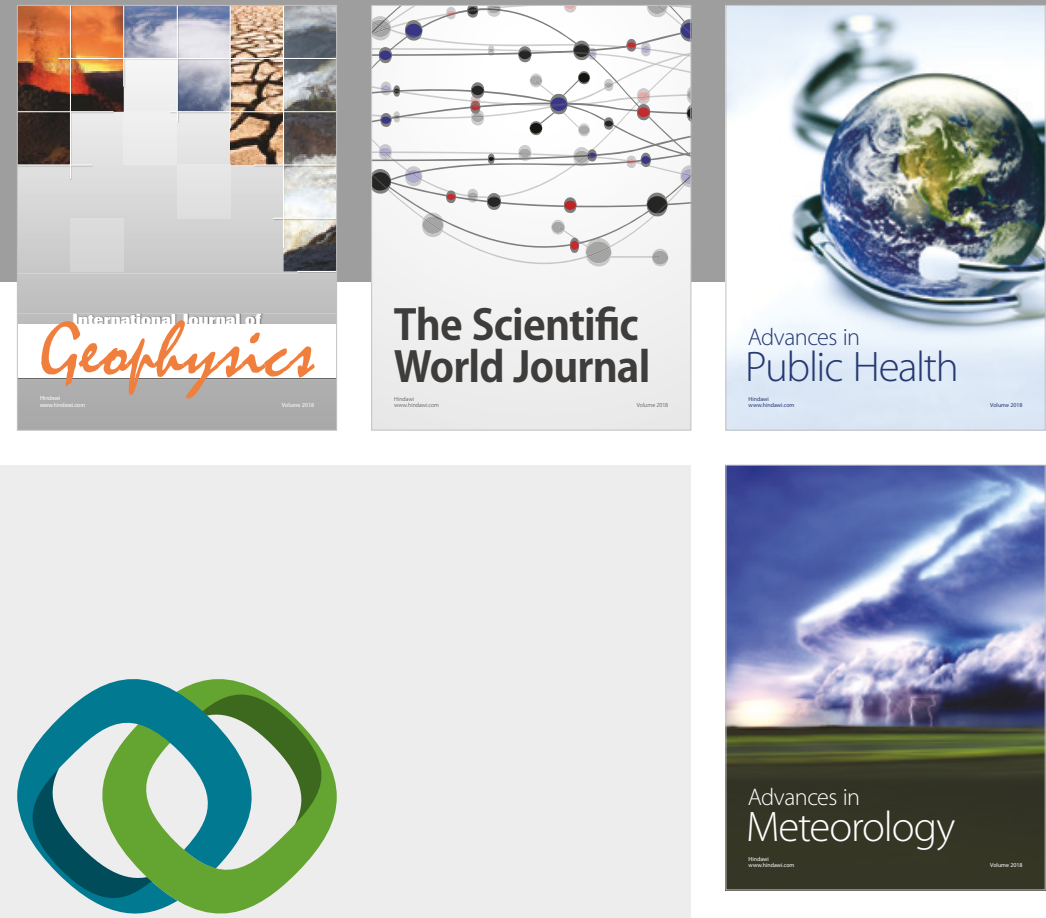

Advan

Public Health

\section{Hindawi}

Submit your manuscripts at

www.hindawi.com
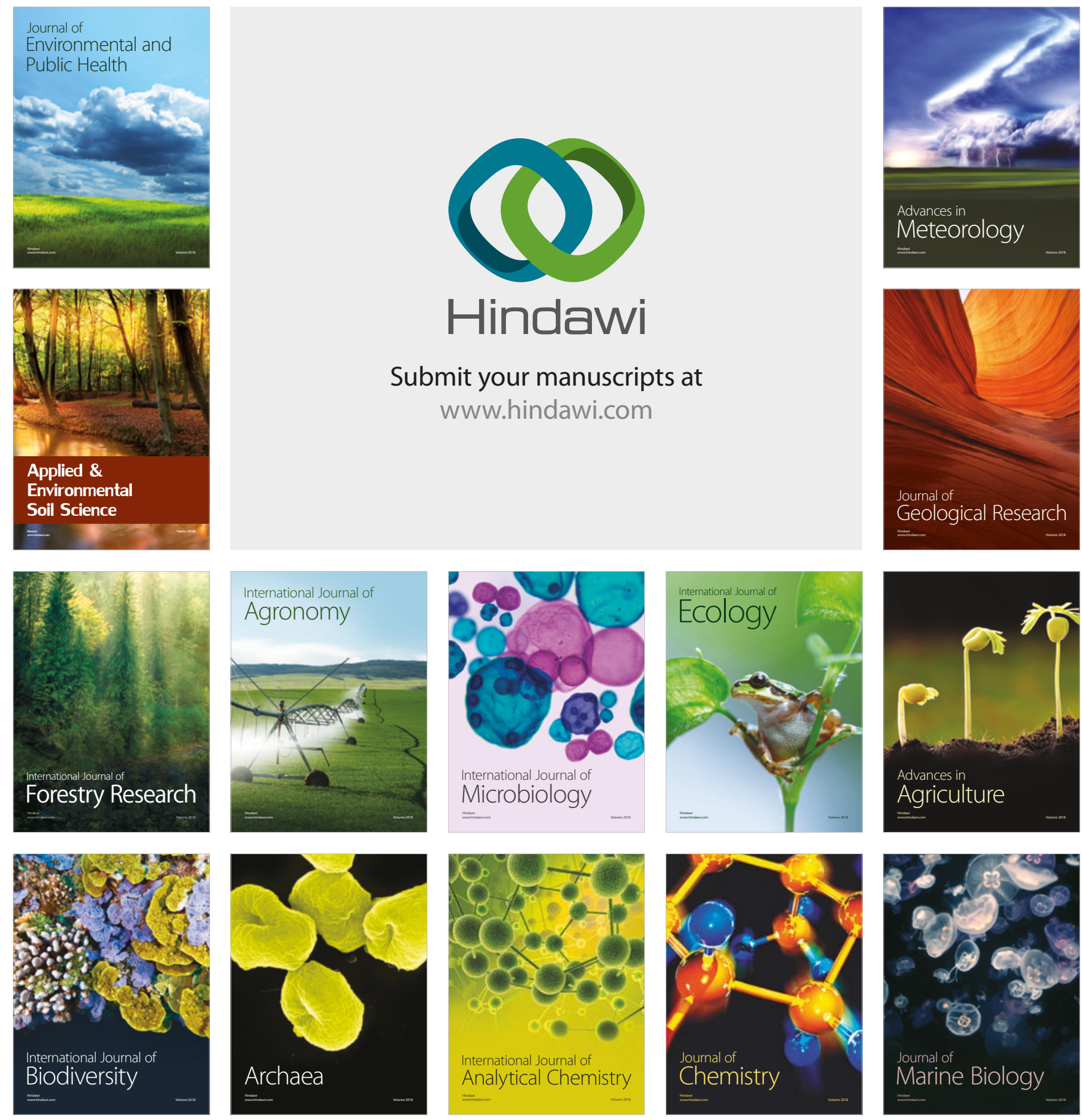